\title{
Влияние морфологии супраструктуры поликристаллических пленок халькогенидов свинца на спектральную плотность мошности шума
}

\author{
И.Н. Мирошникова ${ }^{1,2)}$, Б.Н. Мирошников ${ }^{1,2)}$, М. Ю. Пресняков ${ }^{3)}$, В.П. Астахов ${ }^{4)}$ \\ ${ }^{1}$ Национальный исследовательский университет «МЭИ», Москва, 111250, Красноказарменная. 14 \\ тел. 7 (495) 362-7168, эл. почта: MiroshnikovaIN@mpei.ru \\ ${ }^{2}$ Институт нанотехнологий микроэлектроники РАН, Москва, 115487, Нагатинская, 16а, cm. 11 \\ ${ }^{3}$ Национальный исследовательский иентр Курчатовский институт, Москва, 123182, пл. академика \\ Курчатова. 1 \\ ${ }^{4}$ АО «Московский завод «Сапфир», Москва, 117545, Днепропетровский проезд, д. 4а
}

DOI 10.34077/RCSP2019-111

Связь морфологии со спектральной плотностью мощности шума фоторезисторов на основе $\mathrm{PbS}$ детально обсуждалась в $[1,2]$.

Наши исследования в этой области были продолжены на фоторезистивных структурах на основе $\mathrm{PbSe}$ и $\mathrm{PbCdS}$. Данные образцы были изготовлены с целью получения фоточувствительных слоев с высокой чувствительностью в диапазоне длин волн 1,5-5 мкм.

В докладе приведены результаты измерений как значения шума на частотах 400, 800 и 1200 Гц, так и спектральной плотности мощности шума в диапазоне $1-10000$ Гц. Показано, что наличие шума типа $1 / \mathrm{F}$ во всем диапазоне частот напрямую связано со степенью упорядочения полупроводникового материала. Так для субструктур, представленных на рисунке 1 (с приведенными для них картинами дифракции электронов) легко видеть различия между «шумящей» структурой (верхний рисунок) и малошумящей (с преобладанием генерационно-рекомбинационного шума).

Работа проводилась при финансовой поддержке РФФИ (ГРАНТ № 18-29-11051).
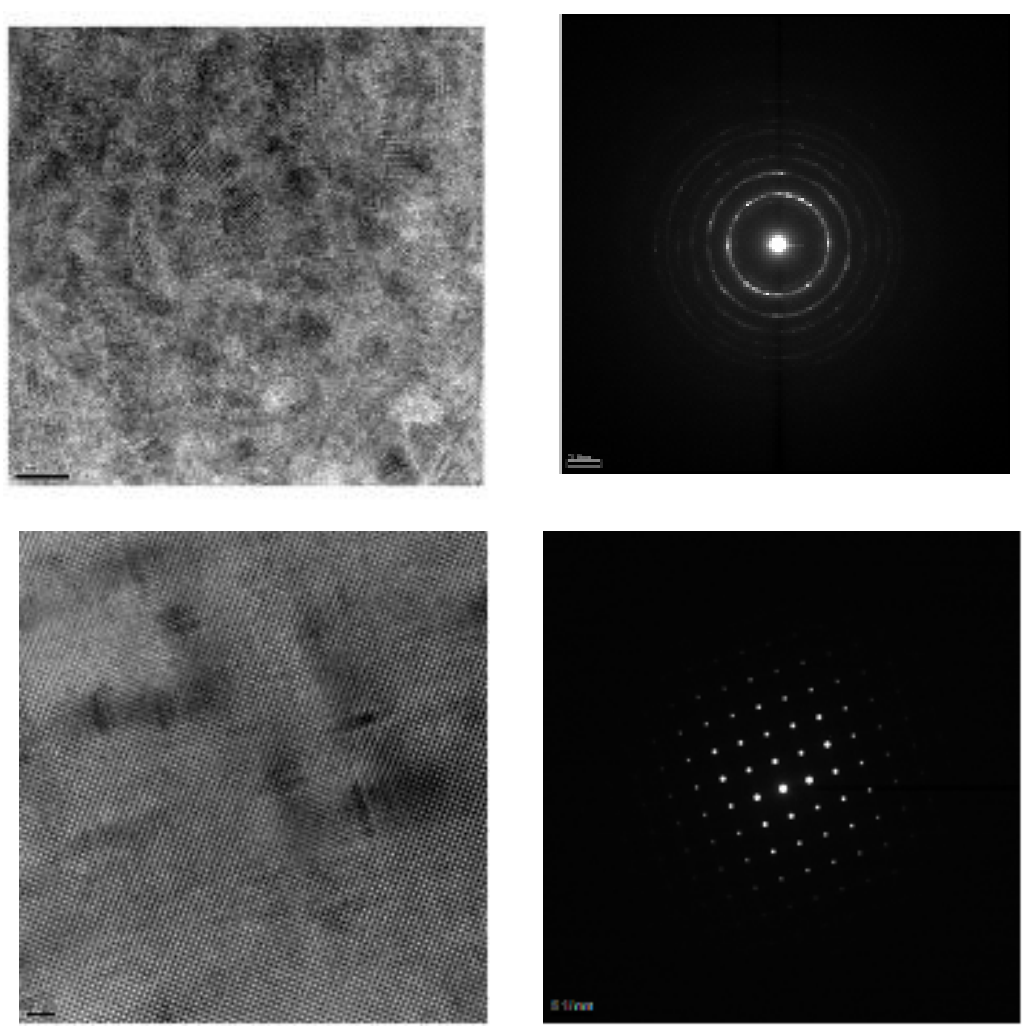

Рис. 1. Строение зерна и дифракционная картина электронов от него

\section{Лuтература}

[1] Б.Н. Мирошников и др. //Измерительная техник. 2015. №2. С. 37-41.

[2] Комиссаров, А.Л. и др.// Вестник МЭИ. - 2010. - №4. - С. 57-62. 